\title{
STUDIES ON PIPER BETLE OF SRI LANKA
}

\author{
LAKSHMI ARAMBEWELA, ${ }^{*}$ K.G.A. KUMARATUNGA ${ }^{2}$ and KALYANI DIAS ${ }^{3}$ \\ ${ }^{1}$ Industrial Technology Institute, 363, Bauddhaloka Mawatha, Colombo 7. \\ ${ }^{2}$ Food Control Laboratory, Ministry of Health, Anuradhapura. \\ ${ }^{3}$ Betel Research Station, Narammala.
}

(Accepted: 09 December 2004)

\begin{abstract}
More than twelve cultivars of Piper betle are reported in Sri Lanka but no chemical studies have been carried out on them. The present study describes the morphological, physico - chemical, chemical and antimicrobial activities of six main cultivars of $P$. betle Linn namely Galdalu, Mahamaneru, Kudamaneru, Ratadalu, Nagawalli and Malabulath. The chemical constituents identified in the essential oil of Malabulath by Gas Chromatography-Mass Spectrometry (GC-MS) were different to those from the other cultivars. The major compound in Malabulath was allylpyrocatechol diacetate while that in all other cultivars categorized as common betel was safrole. Chemical compositions of the essential oil of the leaf, stalk, stem, fruit and root were different. The major compounds in the leaf, stem, stalk and root oil was safrole but in the fruit it was $\beta$ phellandrene. The composition of the oil also varied with maturity. The essential oil from common betel was active against Escherichia coli (NCTC 10148), Pseudomonas aeruginosa (NCTC 10662), Staphylococcus epidermidis (NCTC 4276), Staphylococcus aureus ( NCTC 8532 ), and Streptococcus pyrogens. The essential oil and the ethanol extract were also active against Cladosporium $s p$.
\end{abstract}

Key words: antimicrobial activities, GC-MS studies, Piper betle, Sri Lanka.

\section{INTRODUCTION}

Piper betle Linn. (Sinhala: Bulath; English: Betel vine) belongs to the genus Piper of the family Piperaceae. ${ }^{1}$ Over 700 species of plants belonging to the genus Piper are found distributed in both hemispheres. ${ }^{2}$ Of these about 30 species have been recorded from India. ${ }^{1}$ In Sri Lanka, 18 species are found and three are endemic. ${ }^{3}$

$P$. betle Linn. is cultivated in Sri Lanka, India, Malaysia, Indonesia, Philippine Islands and East Africa. In Sri Lanka, betel is commonly used as a cultural symbolism. ${ }^{4}$ The leaves of this plant are economically and medicinally important. Betel leaves have been traditionally used for chewing purposes along with other condiments. This chewing combination is known as betel quid. Sri Lankan betel industry has a long-standing history dating back to $340 \mathrm{AD} .{ }^{4}$ Colombo,
Gampaha, Kalutara, Kurunegala, Kegalle, Ratnapura, Matale and Galle are the main betel cultivating districts in the country. In Sri Lanka, more than twelve cultivars of betel have been recognized by the villagers but no systematic nomenclature and scientific classification of these cultivars are recorded. The objectives of the present study are to identify the different cultivars of betel found in Sri Lanka using morphological characters and chemical properties of the oil.(to assist a scientific classification of the different $P$. betle Linn. cultivars found in Sri Lanka). In most of the plants the constituents depend on the maturity and the part analysed. Hence in the present study, the chemical constituents of the essential oils from different parts of the plant at different maturity levels were also investigated.

Antimicrobial properties of $P$. betle Linn. found in India are reported ${ }^{1}$ but no studies on the plants found in Sri Lanka are available. Hence a study on the antimicrobial properties too was carried out.

\section{METHODS AND MATERIALS}

Plant material : $P$. betle plant materials were collected from Narammala, Panduwasnuwara, Thissawa, Thabbomulla, Walpitagama, Udagama (Kurunegala district), Wadinapaha, Divulapitiya, Dewalapola (Gampaha district), Karagoda, Bibullawella, Uyangoda (Matara district) and Hiyara east, Akmeemana, Yakkalamulla, Paradaradeniya (Galle district). Six cultivars of $P$. betle namely Galdalu, Mahamaneru, Kudamaneru, Ratadalu, Nagawalli and Malabulath were used in the present study. From 5-6 plants of each type 6-8 wk old leaves ( $250 \mathrm{~g}$ ) from the sixth to eight position from the apex of the vine were collected along with some plagiotrophic branches. The roots and the fruits 
from the same plant were also collected. The samples were identified by the third author.

Morphological studies: Morphological observations regarding colour and size were recorded for each of the leaf samples collected. Internodal distances of the plagiotrophic branches of each sample were measured.

Study of the anatomy: Cross sections of the stem and leaf of each of the samples were obtained and stained. These cross sections were mounted and observed under the microscope. The microscopic photographs were taken and used for comparative study. Similarly microscopic cross sections of the leaves were photographed and studied.

Five betel leaves were selected from each sample. From each leaf the lower epidermal peels were trimmed from the leaf lamina between the tip and the base and from half-way between the margin and the mid rib. The lamina peels of each were examined under the microscope using grid eye piece. The stomatal indices were calculated using the Salisburgs formula.

Determination of the moisture content: The leaves $(5.11 \mathrm{~g})$ were dried in an oven at $105^{\circ} \mathrm{C}$ for $2 \mathrm{~h}$, cooled and weighed. The procedure was repeated till a constant weight was obtained. The determination was done in triplicate. Similarly the moisture contents in the stem, the stalk, the fruit and the root of common betel were determined.

Determination of the essential oil content : Fresh leaves $(251.9 \mathrm{~g})$, roots $(160.7 \mathrm{~g})$, stems (175.8 g), stalks $(245.9 \mathrm{~g})$, and fruits $(176.7 \mathrm{~g})$ obtained from each cultivar except from the cultivar identified as Malabulath were cut in to small pieces and the essential oil extracted separately as follows. In the case of Malabulath only the leaves were used for the extraction. The cut plant materials were separately water distilled for $6 \mathrm{~h}$ using a Clevenger oil arm fitted with condensers through which cooled water was circulated to prevent low volatiles from escaping. The volatile oil was collected in hexane-pentane mixture. The yield was calculated on a dry weight basis. Determinations were carried out in triplicate.
Determination of the physical properties of the essential oil: Refractive index of the oil was measured using an Abbe Atogo IT refractometer. The temperature was maintained at $23^{\circ} \mathrm{C}$ using a thermostat controlled water circulator. Specific gravity of the oil was measured using a specific gravity bottle.

Preparation of the ethanol extract: Fresh leaf samples ( $20.8 \mathrm{~g}$ ) were cut into small pieces and refluxed with ethanol $(400 \mathrm{ml})$ using a Soxhlet extractor for $8 \mathrm{~h}$. The extract was evaporated under reduced pressure and a dark brown mass $(0.96 \mathrm{~g})$ was obtained.

Determination of the chemical constituents of the essential oil : The volatile oil extracted from each of the betel cultivars was subjected to Gas Liquid Chromatography (GLC) analysis using Shimadzu GC - 14 B equipped with FI detector and Supelcowax TM-10 fused silica capillary column. Retention data and peak enhancement techniques were used for the identification of compounds. The GLCs of cultivars Galdalu, Mahamaneru, Kudamaneru, Ratadalu and Nagawalli were similar and they were referred to as common betel. The volatile oil from the leaves, stalks, stems, fruits and roots of common betel and from the leaf of Malabulath were subjected to the GC-MS using Hewlett-Packard 5890 Series II equipped with FI detector and DB$5 \mathrm{MS}$ capillary column. The volatile oils of young and mature P.betle leaves of common betel were also analysed .

Antibacterial screening: In the antibacterial studies cultivars Galdalu, Mahamaneru, Kudamaneru, Ratadalu and Nagawalli were classified as common betel. The leaf oil and the ethanol extract obtained from the common cultivars of betel were used for the antibacterial studies. The antibacterial activity was studied by the 'Disk diffusion method's using Escherichia coli (NCTC 10148), Pseudomonas aeruginosa (NCTC 10662), Staphylococcus epidermidis (NCTC 4276), Staphylococcus aureus (NCTC 8532), Streptococcus pyogens. The experiment was conducted in triplicate. This method has diffusion and solubility limitations. The MIC values were determined using the serial dilution technique. ${ }^{6}$ 


\section{RESULTS AND DISCUSSION}

Table 1: Morphological features of the different cultivars of betel

\begin{tabular}{lcccccc}
\hline Character & \multicolumn{5}{c}{ Betel Cultivars } \\
\cline { 2 - 7 } Leaf colour & $\begin{array}{c}\text { Malabulath } \\
\text { Yellowish } \\
\text { Green }\end{array}$ & $\begin{array}{c}\text { Galdalu } \\
\text { Yellowish } \\
\text { Green }\end{array}$ & $\begin{array}{c}\text { Mahamaneru } \\
\text { Yellowish } \\
\text { Green }\end{array}$ & $\begin{array}{c}\text { Kudamaneru } \\
\text { Yellowish } \\
\text { Green }\end{array}$ & $\begin{array}{c}\text { Ratadalu } \\
\text { Green }\end{array}$ & $\begin{array}{c}\text { Nagawalli } \\
\text { Green with } \\
\text { yellow patch }\end{array}$ \\
\hline $\begin{array}{l}\text { Internodal } \\
\text { Distances(cm) }\end{array}$ & $10.10-15.70$ & $3.80-12.50$ & $4.00-13.60$ & $6.20-13.20$ & $6.8-13.40$ & $7.60-13.50$ \\
L /W & $1.22 \pm 0.01$ & $1.53 \pm 0.17$ & $1.55 \pm 0.18$ & $1.70 \pm 0.07$ & $1.48 \pm 0.06$ & $1.86 \pm 0.01$ \\
Stomatal index & $7.23 \pm 0.12$ & $9.57 \pm 0.64$ & $9.32 \pm 0.45$ & $9.34 \pm 0.40$ & $9.98 \pm 0.88$ & $10.03 \pm 0.92$ \\
\hline
\end{tabular}

Table 2: Morphological characters and stomatal index of common betel and Malabulath

\begin{tabular}{lccc}
\hline Betel cultivar & Leaf length / width ratio & Stomatal index & Leaf colour \\
\hline Common betel & $1.62 \pm 0.16$ & $9.65 \pm 0.69$ & Green - yellowish green \\
Malabulath & $1.22 \pm 0.01$ & $7.27 \pm 0.12$ & Green - yellowish green \\
\hline
\end{tabular}

Table 3: Comparison of different cultivars of betel

\begin{tabular}{lcccccc}
\hline \multirow{2}{*}{ Character } & \multicolumn{5}{c}{ Betel cultivars } \\
\cline { 2 - 6 } & Malabulath & Galdalu & Mahamaneru & Kudamaneru & Ratadalu & Nagawalli \\
\hline $\begin{array}{l}\text { Moisture } \\
\text { content in leaves }\end{array}$ & $83.75 \pm 0.23$ & $83.22 \pm 1.19$ & $83.21 \pm 2.57$ & $79.49 \pm 4.18$ & $85.13 \pm 0.52$ & $85.28 \pm 0.03$ \\
Oil g/100 g & $1.03 \pm 0.01$ & $1.11 \pm 0.34$ & $1.12 \pm 0.33$ & $1.02 \pm 0.21$ & 0.89 & $0.84 \pm 0.09$ \\
$\begin{array}{l}\text { Specific gravity } \\
\text { Refractive index }\end{array}$ & 1.03 & 1.05 & 1.05 & 1.05 & 1.05 & 1.05 \\
$\begin{array}{l}\text { EtOH extract } \\
\text { g/100 g }\end{array}$ & $32.75 \pm 0.06$ & $40.50 \pm 8.14$ & $42.91 \pm 4.74$ & $33.27 \pm 1.26$ & $40.91 \pm 2.3741 .88 \pm 0.55$ \\
\hline
\end{tabular}

Table 4: Major compounds identified by GLC from the volatile oil of the leaf of six betel cultivars

\begin{tabular}{lcccccc}
\hline \multirow{2}{*}{ Cultivar } & \multicolumn{6}{c}{ Compounds } \\
\cline { 2 - 7 } & $\beta$-Phellandrene & 4-Terpineol & Safrole & Eugenol & $\begin{array}{c}\text { Chavibitol } \\
\text { acetate }\end{array}$ & $\begin{array}{c}\text { Allylpyrocatechol } \\
\text { diacetate }\end{array}$ \\
\hline Galdalu & 3.8 & 2.03 & 37.5 & 17.2 & 1.1 & 1.1 \\
Mahamaneru & 6.1 & 3.8 & 33.1 & 9.26 & 6.74 & 6.82 \\
Kudamaneru & 1.62 & 2.5 & 35.7 & 19.9 & 3.8 & 1.74 \\
Ratadalu & 1.76 & 11.0 & 37.5 & 10.5 & 2.96 & 3.54 \\
Nagawalli & 5.5 & 2.5 & 36.6 & 8.5 & 6.7 & 3.5 \\
Malabulath & 6.93 & - & - & - & - & 34 \\
\hline
\end{tabular}




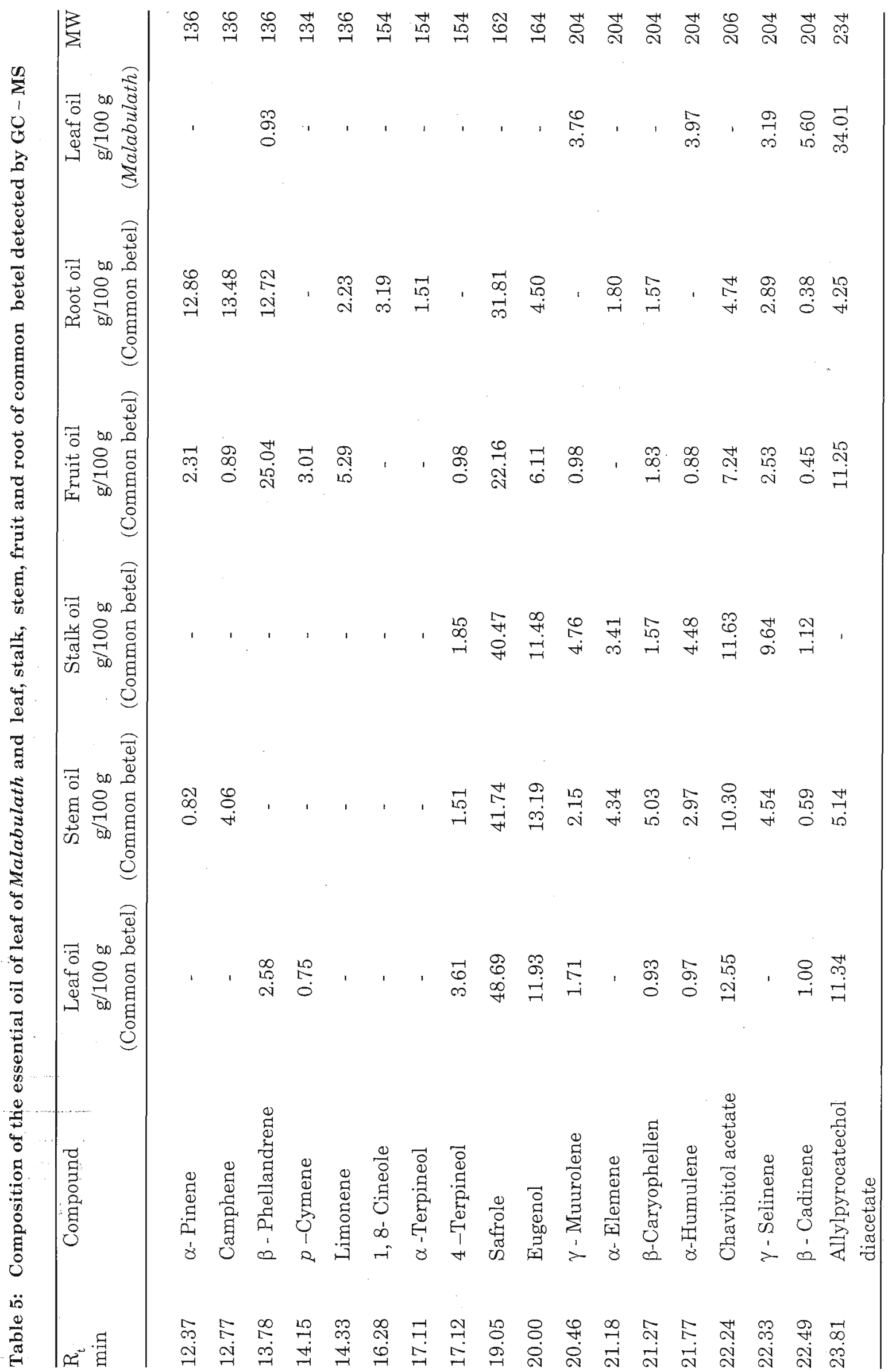


Table 6: Effect of stage of maturity on the composition of the major compounds in common betel leaf oil

\begin{tabular}{lccc}
\hline Compound & Young stage & Harvesting stage & $\begin{array}{c}\text { Mature stage } \\
\%\end{array}$ \\
\hline Safrole & $\%$ & 48.69 & 38.71 \\
Eugenol & 27.98 & 11.73 & 9.72 \\
Allylpyro catechol diacetate & 13.41 & 11.34 & 11.38 \\
Chavibitol acetate & 1.17 & 12.55 & 6.70 \\
B-Phellandrene & 2.12 & 2.58 & 2.55 \\
\hline
\end{tabular}

Antifungal study: The antifungal activity was studied by the Bioautographic TLC Assay ${ }^{7}$ using Cladosporium sp. The experiment was conducted in triplicate.

According to morphological and anatomical studies the parameters such as stomatal index and leaf length to width ratio were similar in Kudamaneru, Mahamaneru, Galdalu Ratadalu and Nagawalli but different in Malabulath.(Table 1\&2). The physical parameters of the essential oil (Table 3 ) and constituents of the essential oils of Kudamaneru, Mahamaneru, Galdalu, Ratadalu and Nagawalli too were similar but were different to those of Malabulath. Safrole was detected as the major compound in the leaf oil of common betel but Allyl pyrocatechol diacetate was the major compound in the leaf oil of Malabulath. Hence the results show that the cultivars of betel analysed in the present study fall into two chemically and morphologically different groups namely Malabulath and common betel. Common betel includes Kudamaneru, Mahamaneru, Galdalu, Ratadalu and Nagawalli. The appearance of Nagawalli leaves differed from the other cultivars. Therefore it can be concluded that chemotaxanomically there are two different groups of betel in Sri Lanka namely Malabulath and the other referred to as common betel.

Over 100 cultivars of betel have been identified by farmers and traders in India. ${ }^{8}$ The chemical studies on $P$. betle of India have revealed that composition of the volatile oils in the leaves can be used as markers for the identification of different cultivars ${ }^{9}$. The chemical composition of common betel oil of Sri Lanka appears to be closer to that of cultivar, Deshawari in India. ${ }^{9}$
GC-MS analysis of oil of Malabulath and common betel leaves indicated that the major constituents of common betel oil are safrole (48.69 $\%$ ) and chavibitol acetate (12.55\%) while Malabulath does not contain these two compounds (Table 5). The major compound in Malabulath oil is allylpyrocatechol diacetate $(34.01 \%)$ which is the third major compound in common betel oil (11.34\%). Further p-cymene, 4-terpineol, safrole, eugenol, $\beta$-caryophellene and chavibitol acetate detected in common betel leaves were not detected in Malabulath.

Hence in the present study GC-MS and microbiological studies were carried out considering the cultivars Kudamaneru, Mahamaneru, Ratadalu, Galdalu and Nagawalli as one group and referred to as common betel.

The GC-MS analysis of the essential oil of different parts of common betel (Table 5) indicated that the composition of the stalk was different to that of the other parts. The stalk did not contain detectable amounts of allylpyrocatechol diacetate. The major compound detected in the oil from the leaf, the stem, the stalk and the root was safrole but in the fruit, it was $\beta$ phellandrene.

Table 6 indicates that the composition of the oil also differs according to the stage of maturity of the leaf. It was observed that the major compounds safrole (48.69\%) and chavibitol acetate $(12.55 \%)$ content in the leaf was maximum at harvesting stage. Further it is seen from table 6 that eugenol and $\beta$-phellandrene content decreased with maturity. It was observed that $\beta$ phellandrene content remained constant after maturity. Allyl pyrocatechol diacetate content 
increased up to harvesting stage and remained constant thereafter.

The change in the composition of the oil with maturity and the part of the plant explains why the ayurvedic physicians specify the maturity of the plant and part of the plant in drug preparations.

The antimicrobial activity of local $P$. betel leaf oil and the ethanol extract has not been studied previously. In the antibacterial study the essential oil from the common betel leaves showed activity against Escherichia coli, Streptococcus pyogenes and Staphylococcus aureus. The MIC values were $3.12 \times 10^{2}, 2.50 \times$ $10^{3}$, and $5.00 \times 10^{3}$ respectively. The ethanol extracts showed high activity against Streptococcus pyogenes, Escherichia coli and Staphylococcus aureus. The MIC values were $1.25 \times 10^{3}, 5.00 \times 10^{3}$ and $5.00 \times 10^{3}$ respectively (Table 8 ). This antibiotic activity can be related to the

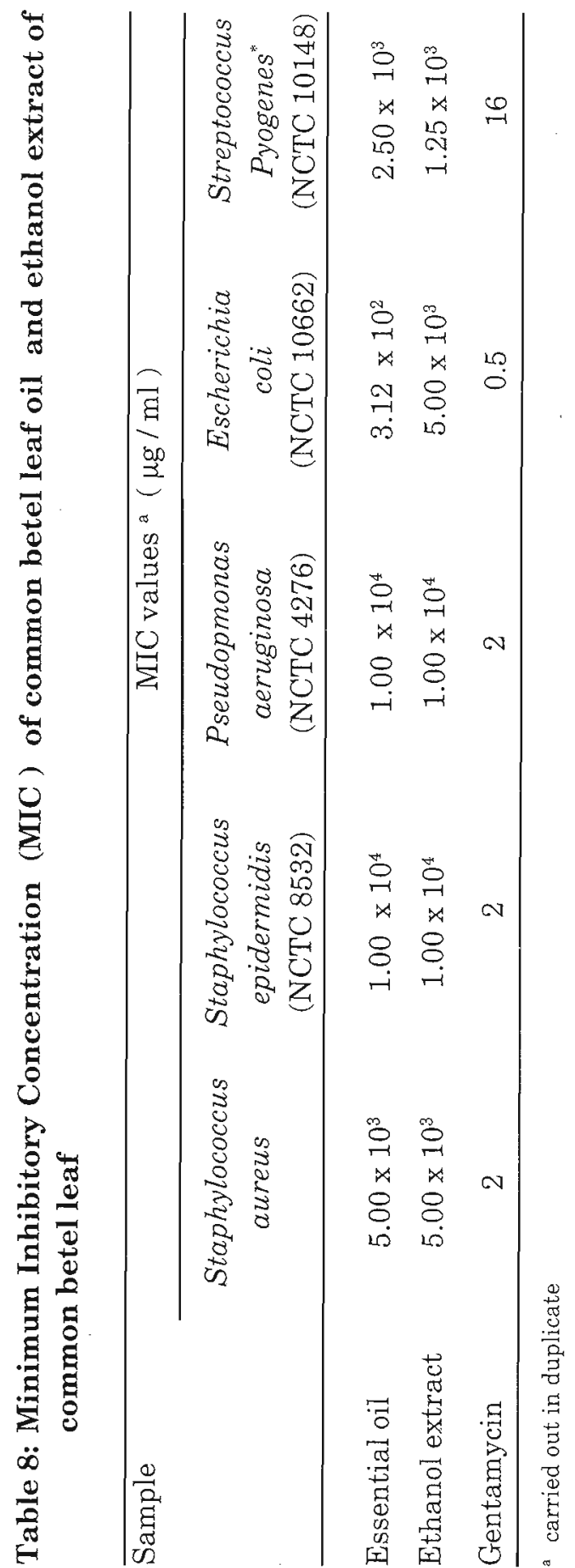


use of this plant as an antiseptic in Ayurvedic medicine.

Antifungal activity of $P$. betle on Cladosporium sp. has not been previously reported. The antifungal activity against Cladosporium sp. indicates that the essential oil of $P$. betle possess at least three fungicidal compounds having $R_{f} 0.54,0.40,0.11$. The ethanol extract contained at least one fungicidal compound having $R_{f} 0.61$ on silica gel TLC plates. These studies will be useful in the development of value added products from betel.

\section{Acknowledgement}

The authors are grateful to the Council for Agriculture Research Policy for financial assistance and to Dr. Noel Owen of USA for recording Mass spectra.

\section{References}

1. Traditional Asian Medicines and Natural Products. Piper Linn.(Piperaceae) [monograph on CD-ROME] discD2. (1997). Wealth Asia. Asian Health Environmental and Allied Database.

2. Parmar V.S., Jain S. C. \& Bisht K. S. et al. (1997). Phytochemistry of genus Piper. Phytochemistry 46 (4) : $597-673$.
3. Dassanayake D.M. \& Fosberg (1981).A Revised hand book of the flora of Ceylon. Vol. VI : pp.222300. Smithsonia Institute and National Science Foundation, Washington.

4. Anonymous (1997). Betel industry of Sri Lanka, present problems and future prospects. pp. 1-25. Economic research unit, Department of Export Agriculture, Sri Lanka.

5. Bawre A.W. \& Kirby W.M. (1966). Antibiotic susceptibility testing by a standardized single disk method. American Journal of Clinical Pathology 45 : 493.

6. Barry A.(1976). The Antimicrobic Susceptibility Test: Principles and Practices. pp. 236 Lea \& Febiger, Philadelphia.

7. Homans A.L \& Fuchs A. (1970). Direct bioautography on thin layer chromatogram as a method for detecting fungitoxic substances. Journal of Chromatography 51: 327.

8. Sharma M.L., Balasubramanyam V.R., Rawat A.K.S. \& Singh A. (1983). Studies on essential oil of betelvine leaf. Indian Perfumer 27 (2): 91.

9. Balasubramanyam V.R. \& Rawat A.K.S. (1990) Studies on morphology and chemistry of Piper betle L. Journal of Plantation Crops 18(2): 78-87. 